\title{
The Culture Turn in Translation Studies
}

\author{
Chen Yan, Jingjing Huang \\ School of Foreign Languages, China University of Political Science and Law (CUPL), Beijing, China \\ Email: susan banban923@hotmail.com
}

Received 20 August 2014; revised 30 August 2014; accepted 5 September 2014

Copyright (C) 2014 by authors and Scientific Research Publishing Inc.

This work is licensed under the Creative Commons Attribution International License (CC BY). http://creativecommons.org/licenses/by/4.0/

(c) (i) Open Access

\section{Abstract}

The culture turn of translation studies was initially put forward by Bassnett and Lefevere (1990) cultural approach in 1990. As important representatives of cultural approach in translation studies, Bassnett and Lefevere attached great importance to the role of culture in translation, the social background, the influence that cultural tradition imposed on translation, the subjectivity of translators and researching shift from linguistic to culture, thus improving the literariness of translated texts. Such method of study expanded the scope of translation studies enormously, opened a new field of study, thus it enhanced a further and more comprehensive development of translation studies. This paper will present a brief introduction of the history of translation studies, analyzing the social causes of culture turn and especially discuss the series shifts brought by culture turn in status of translated texts and translators, and the methods of translation analysis. In the end, some personal viewpoints will be showed about the culture turn in translation studies.

\section{Keywords}

Cultural Approach, Culture Turn, Translation Studies

\section{Introduction}

Since the creation of languages, translation began to come into being. Though translation has a long history, in the beginning, people simply translated just for communication and then made sense of what the other party expressed. In general, at that time, there existed no professional translators for the sake of popular self-contained life style. However, industrial revolution opened the door of socialization big production, and the productivity was soared and new vehicles came up. So products were sold to every corner of the world to gain excessive profits and cheap raw materials were imported from other countries. As the increasing exchanges among different language areas in trade, translation was playing a more and more important role in communication, and professional translators began to work for the massive needs. In the late 1970s, translation studies began to be taken seriously by some linguists and translation theorists to give a guide of a proper and suitable translation. Then a 
special science-translation studies arisen.

A number of researches have been conducted to investigate the translation methods. Since the late 1970s, the linguistic approach of translation substituted for the originally dominated word-to-word method which was usually obscured for readers. And the dynamic equivalence was put forward by Nida, which marked a new advance in translation studies. Nida who was a Bible translator has pointed out that "the relationship between receptor and message should be substantially the same as that which existed between the original receptors and the message” (Nida, 1964: p. 159). From his point of view, translation should vary for the sake of different readers. For example, translation for children must be easy to understand and interesting to convey the surface meaning, whereas for expertise must be professional. Chinese famous translation theorist, Ye Zinan thought highly of Nida's ideas in his book Translation Theory and Practice. Dynamic equivalence was indeed a prominent advance in translation studies. In his theory, he began to throw away the simply literal translation and took the different social background into consideration. He paved a way for the cultural approach in translation studies. Nida was honored with "the patriarch of translation studies and a founder of the discipline" (Ma, 2010: p. 4). However, in his practice, he just paid attention to the local habit of language use, emphasizing the language equivalence but irrespective of other social and cultural elements, which might made the texts understandable. At the same time, this method was hard to meet the need of massive translation and the target readers were hard to determine, especially the literature's readers. Considering that, Hans J. Vermeer created skopos theory, announcing that translation is a type of human action, an intentional, purposeful behavior that takes place in a given situation (Ma, 2010: p. 81). Skopos, the intention of translation, determined the translation methods and strategies (Xie, 2012: p. 159). From this respect, the status of source text was decreased, and more attention was paid to the function of the translated text. However, it was almost suitable and valid for advertisement translation which attached more importance to the effects of ads and some other non-literal texts (Ma, 2010: p. 90). Then Christiane Nord added loyalty to such sokops theory, emphasizing the translators' responsibility toward the author, the initiator and the target recipient (Nord, 2001: p. 14). In other words, Nord's theory was similar to Nida's. Though all of these scholars built up their theories upon linguistics, they began to recognize the social elements. Polysystem theory came into being under such circumstance, breaking the boundary of traditional linguistics and culture. Polysystem theorists thought the receptor's social norms and literary tradition decided translators' Aesthetic hypothesis, and then influenced the translation procedure (Liao, 2006: p. 61). Itamar Even-Zohar divided literature into "center" and "periphery”, and the translation differed according to it. If a kind of literature was young or periphery in a nation, then the translation should dominated and was foreignized to import more new ideas. If the literature was strong or center in a society, then the translation should be domesticated based on local culture tradition. But just as Xie Zhentian has pointed out: “How to define 'center' and 'periphery'? Is this a political or a literary standard? (Xie, 2012: p. 219)” Though Toury and some other theorists developed polysystem, they could not avoid such flaws. Based on the above researches, in the 1990s, Translation, History and Culture co-authored by Susan Bassnett and Andre Lefevere formally put forward the idea of culture turn, which aroused many scholars' attention. They advocated cultural approach in translation studies to combine cultural factors such as sociology, psychology with the translation and to improve the literariness of translated texts. Until now much research has done in culture turn translation studies, but some questions still remain to be further clarified, especially some questions about culture. Some disputes on when culture turn began, why culture turn was necessary and how to balance cultural factors and sense still existed.

The purpose of this study was to investigate the culture turn in translation studies. Three questions were listed as follows: 1) why is culture turn there in translation studies? 2) How does the culture function in translated texts? 3) How does the culture turn affect the translation studies?

The study was in four phases. In phase one, a brief study of the history of translation studies was carried out to present the general development of translation studies, clarifying the tendency of its development. In phrase two, a research of social causes of culture turn will be conducted. In phase three, some analysis on the shifts that culture turn has brought in translation studies will be presented. In phase four, some advice on how to practice culture turn in translation would be given for the sake that all the theories come from practice and should be applied in practice.

\section{The History of Translation Studies}

“Translate” has two meanings_-to change speech or writing into another language; to change something from 
one form into another" (Yang, 2009: p. 2136). Here, the "translate" this paper discussed only refers to the language shifts of writing. And, "translation" also has two meanings- the act of translating something or something that has been translated" (Yang, 2009: p. 2136). So generally, translation studies involve the research of the process of translating and the translated texts. However, this paper tend to the study of the process but a simply study of the translated texts.

\subsection{Linguistic Approach in Translation}

Linguistic approach was a milestone in the development of translation theories. Its main representative was Nida who published his masterpiece-Toward a Science of Translating in 1964, emphasizing transformational generative grammar which was created by Chomsky. Nida pointed out that every sentence had its essential meaning, which was unchangeable even as the language changed, and he called it as kernel sentence (Liao, 2006: p. 58). In his theory, every sentence can be analyzed and found out the underlying meaning which did not depend on the words but existed forever. Of course, it can be transformed into another language with different structure. Based on this theory, it can be seen the shift from literal translation to free translation, irrespective of the form of texts. It emphasized the contexts and gave both of the source-language reader and the receptor-language reader the same understanding, which was called dynamic equivalence. Nida' theory was praised by scholars from the world, especially Chinese scholars such as Ye Zinan and Ma huijuan. Such theory was especially suitable for Bible translation, which focused on the spread of the meaning, and the advertisement translation. However, the equivalence of contexts seemed not enough. The sacrifice of form must lead to the loss of stylistic traits and literariness of texts since a good article mostly succeed in its good structure. For example, a poem had better be adapted into an essay to keep its content according to Nida's theory. Then what was the point of the poem? On the other hand, every country had its special culture which was rarely translated into other countries' culture. For example, there was not a similar festival in China to Christmas in United States as they had different customs. So it was hard to shift Christmas into a Chinese festival. In the contemporary global world, such translation theory could not meet the need of various translations with various purposes.

\subsection{Functionalist Approach in Translation}

Functionalist approach in translation studies mainly considered the purpose and function of the translation, researched the intention of purpose and form during the procedure of translation and the function of the translated texts in receptor-language environment (Zeng, 2010: p. 131). Different from linguistic approach, functionalist approach attached more importance to the function but not the language equivalence. Katharina Reiss and Hans Vermeer were the critical representatives. Vermeer created skopos theory, meaning every translation had its own unique purpose and function which decided the method to translate it. That was to say, results decided the process. According to such theory, a source text could be translated into various versions with regard to various functions or purposes. Instead of equivalence, it pursued their destination. For example, a serious novel may be translated into a fiction catering to the favor of the public. The status of the source text was reduced. In such a world that was full of all kinds of needs and favors, functionalist approach was a good method since literature could diversify. For example, a poem could be translated into a drama and screened into a theater to color people's life. However, this approach should have its scope of application. Mostly, the great texts could be translated into other languages to make more people enjoy its beauty. A translator, in general, played as a media to bridge the source text and the translated text. If too much information had been adapted, what was the force of the text? On the other hand, generally a translator did not clear the function of a literary text. After skopos theory, Lefevere put forward the theory of adaption which was one field of skopos theory, as it were. In fact, functionalist approach valued the situation of the society. It was obvious that the theory began to add the social circumstance into the translation. But this approach to some degree was not appropriate, for that has violated the essence of translation. Instead, it could be regarded as recreation which called talents in writing for a translator but not only the language. It seemed a little harsh for translators.

\subsection{The Cultural Approach in Translation}

In 1990, Bassnet and Lefevere co-published Translation, History and Culture, formally putting forward the idea of cultural turn in translation. Cultural approach emphasized especially the important status of culture in transla- 
tion and the cultural influence of translation in receptor-language region, treating translation as independent literature but not the mere copy of original texts. Different from the traditional approaches which aimed at convey of message or function, cultural approach put translation into the wide cultural environment, focusing on the cultural contexts, history and the norms (Zeng, 2006: p. 45). It provided a new perspective of translation studies. Polysystem theory was one typical example of cultural approach, though it was put forward before the born of culture turn. Polysystem theory emphasized the whole cultural environment to decide the method to translate texts. In the 1990s, cultural turn tended to be political, and finally developed into feminist approach, cannibalism and post-colonialism approach. They, on the other hand followed the functionalist approach whose functions varied. But cultural approach at that time just had one function, propagating their political tendency or something else. Obviously, those theorists misunderstood the meaning of cultural approach.

\section{Social Causes of Culture Turn in Translation Studies}

Culture turn in translation studies was not turned up casually but had its deep social reasons. At the same time it was not put forward by Bassnet and Lefevere abruptly but came into being gradually. Bassnet and Lefevere just took advantage of the proper opportunity and made it formally known by the public. The social causes of culture turn in translation studies was complex. From the word-to-word translation to translation involving the background, the reality and the environment, it was a long and gradual history. First and foremost, culture turn in translation practice led to its studies. Here, this paper would deduce it based on the development of functions of translation.

\subsection{A Brief Introduction of Functions of Translation}

Reviewing the history of translation and translation studies, the functions of translation can be classified into four categories. First, in the early time that translation began, it was a tool of simple communication. For example, in early sales of goods, people from different circles of language translated to finish their trade. At that time, few requirements were asked in translation. The only requirement was that the other party could understand the basic meaning of the speech. Second, translation was used to propaganda religious belief. Bible has long been translated into various languages to propaganda its religious belief. Nida was one of the most prestigious representatives in Bible translation. Third, through translating, some advanced or useful ideas could be introduced to promote the political events of the society. For example, at the beginning of 20th century, Marxism was translated into Chinese to serve as a tool to infuse new ideas and topple the old feudalism. So in the translated texts, ideas about the communism were to some degree, exaggerated and some other subtlety was ignored for political needs in China. This function was used by many countries with different purposes. The forth function which was popular in modern society, was to introduce new knowledge with few political purposes. Different causes of culture turn in translation studies can be concluded from the diversified functions.

\subsection{Culture and Translation}

Culture was the creation of human beings within unique times, areas and ethnics, referring to the whole models of a society in cultural beliefs, tradition, system and values. It was the whole behavior model of a society. A nation has not only its own language, but also its own culture, which came into being under the certain natural environment, historical conditions and social reality. The common culture gave birth to the common language. People from different languages needed to exchange and such exchange must be followed by translation since language is the most important instrument for culture. So, it can be seen that culture and culture exchange are the originations of translation, and translation is the product of culture exchange. In other words, translation can never exist without culture. Translation and culture can never be separated. In the past research of translation studies, many theorists limited their focus on the linguistics, emphasizing the shifting of linguistic form and the differences of linguistic system. However, since translating activity was complex involving many social and cultural elements, many issues involved in translating activity could not be explained or analyzed on the dimension of the linguistics. Susan Bassnet has pointed out that operating translating cannot neglect the body that surrounds it, so the translator treats the text in isolation from the culture at his peril (Bassnet, 2012: p. 22). For example, there was an American joke in a newspaper: a man was arrested at the airport. Just because he was greeting his cousin Jack! All that he said was “Hi Jack”, but very loud. Nearly every American laughed when 
heard this. But when it was translated into Chinese, no one knew where the joking point was and it just can never be found! Translating such jokes, culture should be considered seriously to avoid those embarrassed situation. So culture was very crucial to translation. Since the initial translation was word-to-word or literal translation, ignoring the cultural background, the translated texts were obscure and disordered. Even until now, many translators are just at war between literal translation and free translation, irrespective of the essential element-culture.

\subsection{Politics and Translation}

Since culture was crucial to translation, the appearance of culture turn in translation studies seemed natural and necessary. However, it was not the only cause of culture turn. Since translation played a role in promoting political events, politics may be another important clue for culture turn.

It can be seen that during a long time, translation was used to propaganda some ideas. However, different from other translating methods, such translating activity concentrated on the useful messages or messages in favor of one's purposes (Here, the purpose was different from that of functionalists referring. It tended more to the social purposes conforming to one's own culture). Taking the social reality, the background, the public mentality and the political requirements into consideration, translators had to make some difference in receptor texts. The feminist approach in translation was a typical representative. Ma (2010: p. 217) has pointed out that as feminists seek to overthrow the submission of women to men, feminist translation theorists seek to subvert the power of the original over the translated texts by reconsidering the function and value of translation in history. Then feminist translators adopted strategies in translation including meta-texts adding, hijacking and supplement. Feminist theory in translation studies emerged just at the same time of feminism in the 1970s to propaganda their demands for equal relationships between men and women.

Other than that, political accuracy asked for cultural factors, which meant that when translating, translators should give the accurate translation in accordance with the current reality rather than the equivalence of meaning. The translation of the sentence that government of the people, by the people, and for the people, shall not perish from the earth by Abraham Lincoln was a good example. If the translator ignored China's political currency, then the translated sentence may be sophisticate. The result might be that Chinese readers would know what it exactly meant but it seemed awkward and obscure, which was rejected by political requirements. In this term, translation needed the intervention of local culture.

In fact, every document in a country may affect the society, so translators had to take the political currency and custom into consideration.

\subsection{Literary Reality and Translation}

Literary reality in a country, to a large degree, promoted the culture turn in translation and translation studies. The very typical research was the polysystem theory by Zohar and Toury. Even-Zohar posits two interrelated hypotheses: 1 , The position assumed by translated literature in the literary polysystem tends to be a peripheral one except in three special cases; 2, Translation tends toward acceptability when it is at the periphery and toward adequacy when it is at the center (Ma, 2010: pp. 135-136). That was to say, translators should choose translating strategies according to the literary reality of a country weather to domesticate or foreignize the translated texts. In the light of previous discuss in this paper, no more example would be involved here.

\section{The Shifts in Culture Turn in Translation Studies}

Culture turn means the process that cultural approach substitutes for linguistic approach and cultural factors was valued by translation. Different from traditional linguistic approach by which the word, phrase, sentence, and text are the translational units, in cultural approach culture becomes the main translational unit. It emphasizes the important role that culture played in translation, and treats translation as micrographic cultural shift with the studying focus shifting from the source text to translated text, from the author to the translator and the source culture to the receptor culture. The shifts from the traditional approaches to cultural approach were mainly represented by the following aspects.

\subsection{A Perspective Shift from Source Texts to Translated Text}

In traditional translation studies, much more attention was paid to the source texts, which emphasized that the 
translation strategies were decided by the types and nature of source texts. The translation studies were conduct from the perspective of the source text, ignoring the translated texts. J. C. Catford defined translation as the replacement of textual material in one language by the equivalent textual material in another language (Liao, 2006: p. 100). He classified translation as total translation and restricted one. The former referred to the grammar and lexica were replaced by equivalent ones in translation texts. The latter referred to partial equivalence for the source text was lacking in replaceable words. Thus, he came to a conclusion of linguistic untranslatability and cultural untranslatability. Liao Qiyi has criticized that Catford treated translation merely as a branch of linguistic, focusing on the structural shifts of language and refusing translation as an art (Liao, 2006: p. 110). Such idea was also represented by Newmark. Newmark thought an excellent translator should tend to literal translation to guarantee the loyalty to the source text and the more important the language of the text was, the closer the translation should be to the source text. He categorized texts as informative texts, expressive texts and vocal texts. Whereas for the former two categories, translators should adopt semantic translation focusing on the semantic content of the source language, the latter should adopt communicative translation to produce a similar effect between its readers and the readers of the original (Ma, 2010: p. 33). Traditional theorists concentrated on the source texts and regarded them as feudal lords.

Different from the source-text-oriented method, theorists of cultural approaches attached more importance to the translated text and its functions. They no longer thought translated text as an appendix but as an independent literature which played an important role in received culture. Zohar pointed out that translated literature was part of the social-cultural systems (Xie, 2012: p. 218). Zohar thought the translation strategies should not be determined by the source texts but the role of translated texts in social-cultural systems. Ma Huijuan in Selected Readings of Contemporary Western Translation Theories has concluded his theory:

If it is primary, the translator is more concerned with the linguistic and cultural features of the source text to produce an adequate translation, whereas it is secondary, the translator is prepared to emphasize the literary conventions and cultural features of the target system (Xie, 2012: p. 137).

The foreignizing translation strategy by Lawrence Venuti was another typical example of translated-text perspective. He advocated that if the translated texts were introduction of foreign advanced skills or something, then the suitable strategy was to foreignize the translated texts, vice versa. Doughlas Robinson put forward postcolonial approach to translation for the purpose of laying stress on the identity and status of national culture in global context (Hu, 2005: p. 57). From a postcolonial point of view, translation has played an active role both in colonial and postcolonial settings. Translation in one respect became an instrument to fight against hegemonic, thus the relevant translation strategies. These theorists were representatives of cultural approach in translation studies. From the above discussion, it was clear that they tended to study translation from the perspective of translated texts, ignoring the nature of the source texts, which was an important shift of translation studies in culture turn.

\subsection{A Shift of Translators' Status}

Dante. G. Rossetti thought the task of a responsible translator was to deny himself, suppress his creativity and then reproduce truthfully the spirit of the original author. In his point of view, the original author was holy, like a feudal lord and the translator should be loyal to him like a servant. Such idea governed the translation studies for many years. Lawrence Venuti called it the invisibility of translators in his masterpiece The Translator's Invisibility, revealing that the translator's situation and creativity are "invisibility" in contemporary Anglo-American culture (Ma, 2012: p. 191). Hu and Xu (2009: p. 28) wrote in their co-authored journal that invisibility meant no trace of translator should be read in translated literature by readers making it as fluent and natural as native literature. Fu lei, a famous Chinese translator, insisted on the principle in all his life that an ideal translation was just like the one written by the original author in Chinese. In addition, Nida has put it that the translator must be a person who can draw aside the curtains of linguistic and cultural differences, so that people may see clearly the relevance of the original message ( $\mathrm{Hu} \& \mathrm{Xu}, 2009$ : p. 159). Actually it was impossible to achieve that for the numerous disparities of customs and culture and possible lack of literariness. All these in fact ignored the role of translators, and treated them as a translation instrument or servant to original author, refusing any personal idea or style of language. So it was obvious that traditional translation gave too much importance to original authors and lowered the status of translators.

However, theorists of cultural approach represented by Venuti challenged such invisibility fiercely. He 
thought that invisibility in essential was a fiercely and rough adaption of original texts in terms of native value of culture, so it to a large degree suppressed and erased the intrusive value of original texts, which represented the hegemonism of European countries and America and showed disrespect for minors in the sense of hegemonic culture (Hu \& Xu, 2009: p. 29). Although different from Bassnett, Venuti practiced cultural approach in the perspective of minor countries, it provided a new viewpoint of translator's visibility. In general, translator's visibility referred that translator was independent, living in a different environment from the author and possessing different experience and so he would understand the original text in his own way and bring it to the translation (Wen, 2010: p. 34). Translator's visibility added energy to the translated texts, making them readable. Adre Lefevere promoted rewriting in translation studies, focusing on the manipulation of the original text. Thus, the translated texts existed with soul and creativity. When the readers read the translated texts, they would not only have an access to the minds of the original authors, but also feel the charming of translators.

\subsection{A Shift from Logocentrism to Deconstructionism}

For a long time, people were used to defining something, hoping to find out the determined result or answer from a fixed point. That was logocentrism. However, once that fixed point disappeared, confusion was followed. Many translation approaches have influenced by such directed thinking. In the viewpoint of logocentrism, the source text was a stable and sealed system, involving a fixed and unvaried meaning. Richards (1929: p. 76) in his Practical Criticism explained that there existed a unified meaning and unified evaluative system in a literature, thus, a full understanding of the source text and a unified translation were possible. In Richards' view, the essence of translation was a unified and popular understanding of the source text, hence a right translated text. It was similar to Nida's theory which emphasized that the source message could be confirmed and that it was possible for the closest natural equivalent to the source-language message (Ma, 2010, p. 7). However, deconstructionists thought there were difference between what it could refer to and what it had referred to. So the meaning of source text was uncertain. The source text and the translated text had a symbiotic relationship, and the source text could be advanced by the shift of languages. Deconstructionists argued to analyze an issue from multiple perspectives, break the closure of structure and erased the idea of logocentrism. Derrida deconstructed the logocentrism through creating the word differane which combined differ and defer to arouse people's attention to differ, defer and dissemination. He thought meaning as a developing process but not a fixed one (Derrida, 1974). Derrida pointed out that the purpose of translation was to reveal those that was lost or restricted, leash the multi-meanings of the text and conduct shifts among pure languages. Typically he thought the source text depended on the translated text. Then the translated texts were not a servant to the original ones. Deconstructionism brought in a completely new perspective for translating approach, making the translated texts diversified and developing the original one.

\section{Conclusions}

From the above discussion, it can be concluded that culture turn in translation studies was an inevitable tendency. It expanded the research fields of translation studies and provided a new perspective of translation, which showed development of translation studies. It showed respect to native culture and flexible translation. To treat translated texts as independent literature but not merely convey its message did good to boost literature in native countries. Cultural approach brought energy and flexibility to translation. As we know that there may be many translated literature in market with fluent languages and native express, however, one may not feel the beauty of literature in reading it for lack of literariness and material meaning except for conveyance of message. Cultural approach to some degree made up for such loss. At the same time the consideration of native culture, social background and tradition led to vivid and natural literature for native readers.

However, this paper also saw the misusage of cultural approach in translation. There was a group of translators that abuse cultural factors in their translation to please the readers in a way of casual adaption or deletion. For example, technical instruction was not suitable for a cultural approach as it called for precision and professionalization. Since the goal of cultural approach was to make the translation a literature but not mere a translated texts and import advanced culture, translators should balance the benefits. Cultural approach should be adopted within a certain range, which will not change the main idea of the author. So how to achieve it? This paper thought instead of focusing on the mere cultural approach, the best way was to combine cultural approach and linguistic approach in translation, which conveyed the message on the one hand and made the translated 
texts literature on the other hand.

This paper has discussed the culture turn in translation studies, including a brief introduction to the history of translation studies, social causes of culture turn and the shifts it brought up. The history was mainly manifested by the gradual process from linguistic approach to functional approach and cultural approach. Social causes of culture turn involved in this paper the importance of culture in society, the politics and the literary reality in a country. In sequence, this paper analyzed the effects of culture turn in translation studies from the changed status of translated texts and translators and the changed analyzing methods of translation to further strengthen the concept of culture turn. In the end, some personal views were presented about the merits and shortages of culture turn and some advice on practicing it.

\section{References}

Bassnett, S. (2012). Translation Studies. Shanghai: Shanghai Foreign Language Education Press.

Bassnett, S., \& Lefevere, A. (1990). Translation, History and Culture. London: Printer Publishers.

Derrida, J. (1974). Of Grammatology. Baltimore: Johns Hopkins University Press.

Hu, A. J., \& Xu, J. (2009) The Invisibility of Translators: On the Choice of a Translation Style. Chinese Translators Journal, 2.

Hu, D. X. (2005). Inspiration of Postcolonial Theory to Translation Studies in China. Journal of Foreign Languages, 4, Serial No. 158.

Liao, Q. Y. (2006). A Research of Contemporary Western Translation Theories. Nanjing: Yilin Press.

Nida, E. A. (1964). Towards a Science of Translating: With Special Reference to Principles and Procedures Involved in Bible Translating. Leiden: Brill.

Nord, C. (2001). Translating as a Purposeful Activity: Functionalist Approaches Explained. Shanghai: Shanghai Foreign Language Education Press.

Ma, H. J. (2010). Selected Readings of Contemporary Western Translation Theories. Beijing: Foreign Language Teaching and Research Press.

Richards, I. A. (1929). Practical Criticism. New York: Harcourt Brace.

Wen, Y. X. (2010). The Display of the Translator's Subjectivity. Journal of Northern University of China (Social Science Edition), 26, Serial No. 13.

Xie, Z. T. (2012). Contemporary Foreign Translation Theories. Tianjin: Naikai University Press,.

Yang, Z. M. (2009). Longman Dictionary of Contemporary English. Beijing: Foreign Language Teaching and Research Press,

Zeng, W. X. (2006). Rethink the Culture Turn in Translation Studies. Foreign Languages Research, 3, Serial No. 97.

Zeng, X. (2010). The Manipulation in Translation: The Common in Functionalist Approach and Cultural Approach. Journal of Jixi University, 10. 
Scientific Research Publishing (SCIRP) is one of the largest Open Access journal publishers. It is currently publishing more than 200 open access, online, peer-reviewed journals covering a wide range of academic disciplines. SCIRP serves the worldwide academic communities and contributes to the progress and application of science with its publication.

Other selected journals from SCIRP are listed as below. Submit your manuscript to us via either submit@scirp.org or Online Submission Portal.
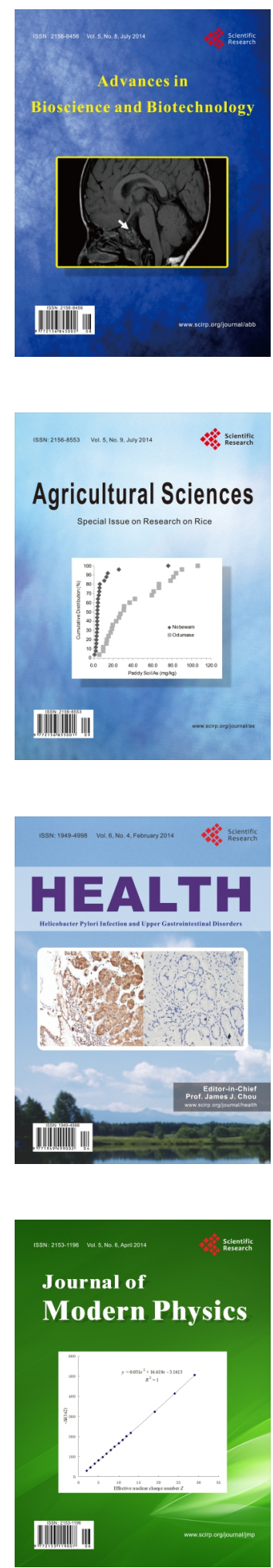
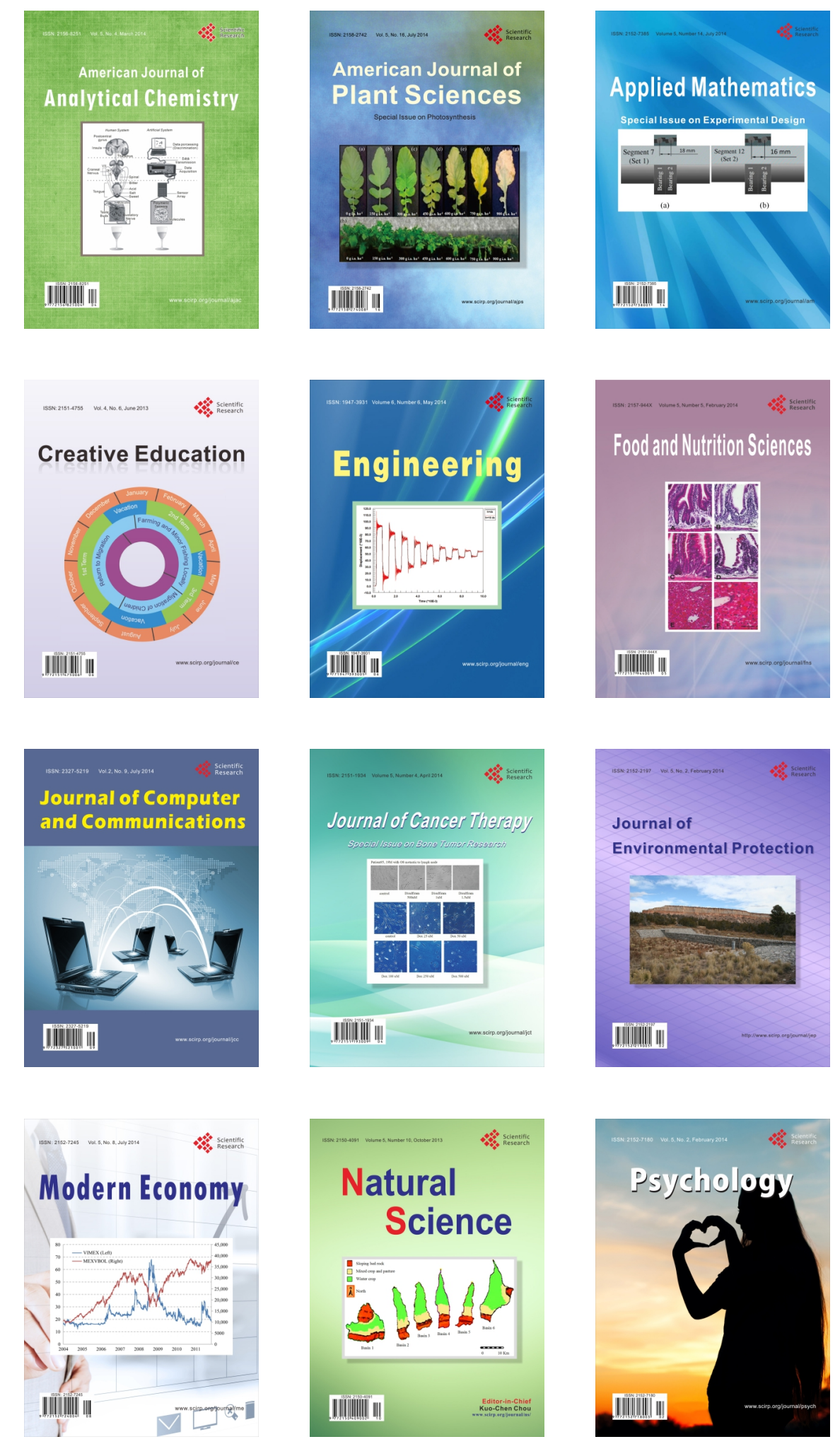